\title{
Depression, anxiety and spirituality in oncology patients
}

\author{
(iD) Karine Corcione Turke ${ }^{1}$ \\ (D) Juliana Seidler Canonaco ${ }^{1}$ \\ (iD) Thiago Artioli \\ (D) Marina Sabin de Souza Lima1 \\ (iD) Amanda Ribeiro Batlle \\ (D) Fernanda Cordeiro Pimentel de Oliveira ${ }^{1}$ \\ (iD) Daniel de Iracema Gomes Cubero ${ }^{1}$ \\ (iD) Claudia Vaz de Melo Sette ${ }^{1}$ \\ (i) Auro del Giglio'
}

1. Centro Universitário Saúde ABC, Santo André, SP, Brasil.

http://dx.doi.org/10.1590/1806-9282.66.7.960

\section{SUMMARY}

OBJECTIVE: To relate anxiety and depression levels to the spirituality levels of oncology patients in the $A B C$ region.

METHODS: Cross-sectional study performed at the ABC University Center oncology outpatient clinics. For the evaluation of spirituality, the Religiosity, Spirituality, and Personal Beliefs instrument of the World Health Organization (SRPB-WHO) was applied. To evaluate the levels of depression and anxiety, the Hospital Anxiety and Depression Scale (HADS) was applied. Qualitative variables were described by frequency and percentage, and quantitative variables by mean and standard deviation or median and range. Relationships were established using either the T-test or Wilcoxon-Mann-Whitney test and correlations with Pearson or Spearman tests, depending on the normality assessed by the Shapiro-Wilk test.

RESULTS: We included 99 patients, $68 \%$ female, with a median age of 60 years (19 to 81). A total of $24 \%$ had high or borderline levels of anxiety and $21 \%$ of depression. There was a negative correlation between levels of depression and spirituality (rho $=-0.44, p<0.001$ ), and anxiety and spirituality (rho $=-0.232, p=0.02$ ). We found no significant difference between levels of anxiety, depression, or spirituality when stratified by schooling, income, ethnicity, or marital status. There was a positive correlation between levels of anxiety and depression (cor $=0.477, p<0.001$ ).

CONCLUSION: Spirituality can be a complementary tool in the treatment of patients with cancer.

KEYWORDS: Neoplasms. Spirituality. Depression. Anxiety.

\section{INTRODUCTION}

Neoplasms, based on estimates from the World Health Organization (WHO), will be the leading cause of death, surpassing coronary heart disease'.
Demographic and epidemiological transitions caused an increase in the number of cases of cancer, in particular in developing or underdeveloped countries ${ }^{2}$.

DATE OF SUBMISSION: 01-Jan-2020

DATE OF ACCEPTANCE: 19-Jan-2020

CORRESPONDING AUTHOR: Karine Corcione Turke

Avenida Lauro Gomes, 2000, Vila Sacadura Cabral, Santo André, SP, Brasil - 09060-870

Telefone: +55 1197393-8012

E-mail: karineturke@hotmail.com 
Regarding Brasil, an increase in mortality is expected due to cancer, particularly in the North and Northeast regions of the country, by $2030^{3}$. Cancer patients, in comparison with patients without the disease, exhibit more symptoms such as fear, despair, emotional and physical exhaustion, and, as a consequence, higher rates of depression and anxiety ${ }^{4}$.

As to psychiatric disorders, anxiety disorders and depression are the most incident worldwide ${ }^{5}$. The World Health Organization, in its Dalys Brasil instrument, makes it clear that neuropsychiatric disorders occupy the second position, after cardiovascular disorders and diabetes. The clinical scenario is often similar and may become chronic or recurrent, affecting the individual's performance and abilities ${ }^{6}$. Thus, these diseases are directly related to a reduction in quality of life and increased mortality and morbidity ${ }^{7}$.

It is estimated that $3.6 \%$ of the world population suffers from anxiety disorders, and females are the most affected. The prevalence of anxiety in the Brazilian population reaches $9.3 \%{ }^{5}$. The WHO estimates that approximately 300 million people worldwide are affected by depression disorders (4.4\% of the population), which are the main cause of disability ${ }^{5}$.

However, the rates of depression vary between different countries, which shows that cultural differences and different risk factors affect the expression of the disease ${ }^{8}$.

In Brasil, it is estimated that the prevalence of depressive disorders in the general population is around $5.8 \%$, and it is more often found in female patients ${ }^{5}$. A meta-analysis identified that approximately $27 \%$ of outpatients have depression or depressive symptoms, varying according to the specialty ${ }^{8}$.

Thus, the data show that Brasil is the country with the highest prevalence of anxiety disorders and the fifth in the ranking of depression ${ }^{5}$.

spirituality has been increasingly used and recognized as a tool for overcoming this issue and as a complementary treatment for cancer patients ${ }^{9.10}$.

Recently, themes such as spiritual well-being and spirituality have been increasingly studied in patients in general, especially in those with cancer ${ }^{11.12}$.

Thus, considering the connections between neoplasms and psychiatric diseases, it makes sense to evaluate the prevalence of the two most common psychiatric disorders (GAD and MDD) in patients undergoing cancer treatment, as well as analyze the relationships between these diseases and spirituality in these patients.

\section{OBJECTIVES}

- Assess the level of spirituality of a population of cancer patients treated in outpatient clinics of the Faculty of Medicine of ABC (FMABC).

- Assess possible correlations between the level of spirituality, demographic variables, and presence of anxiety or depression by the Hospital Anxiety and Depression Scale (HADS).

\section{METHODS}

A descriptive, cross-sectional, and observational study, in which we evaluated the prevalence of major depressive disorder (MDD) and generalized anxiety disorder (GAD) in a group of consecutive patients aged over 18 years and treated in outpatient clinics of the Faculty of Medicine of ABC.

The assessment was carried out through the application of a questionnaire for the patients.

The questionnaire used the Hads ${ }^{13}$ scale for anxiety and depression. In addition, patients' epidemiological and demographic factors were discussed, such as age, sex, race, and marital status. Patients' habits were also assessed, such as the use of alcohol, tobacco, and illicit drugs and the practice of physical activity.

Finally, we analyzed the socioeconomic data, such as average family income (in minimum wages) and formal education. To assess their spirituality, we used the World Health Organization Quality of Life instrument - Spirituality, Religiousness, and Personal Beliefs module (WHOQOL-SRPB) ${ }^{14}$.

The inclusion criteria were patients treated in the oncology clinics of the Faculty of Medicine of ABC and their corresponding hospitals and the completion of the ICF.

The exclusion criterion: incorrect or incomplete filling of the questionnaire.

\section{STATISTICAL ANALYSIS}

The data collected were tabulated and subsequently submitted to statistical analysis. The categorical variables were analyzed for frequency and percentages.

For the continuous variables, was used averages or medians, based on the distribution of the data. We used the Shapiro-Wilk test to determine whether the distribution of the data was parametric or not.

In the continuous data with normal distribution, we used the Pearson's correlation test. For continuous 
data with non-parametric distribution, we used the Spearman correlation test.

For qualitative data, we used the Fisher test or the chi-square test, depending on the size of the sample. Continuous data with qualitative outcomes and normal distribution were evaluated by t-test; and data with non-normal distribution were evaluated by the Mann-Whitney test.

TABLE 1. PATIENTS' DEMOGRAPHIC AND SOCIOECONOMIC DATA AND HABITS

\begin{tabular}{|c|c|c|}
\hline Variable & $\mathrm{N}$ & $\%$ \\
\hline Sex & 99 & \\
\hline Male & 31 & 31.31 \\
\hline Female & 68 & 68.68 \\
\hline Marital Status & 95 & \\
\hline Married & 53 & 55.78 \\
\hline Single & 17 & 17.89 \\
\hline Divorced & 9 & 9.47 \\
\hline Widow(er) & 16 & 16.84 \\
\hline Color & 90 & \\
\hline White & 58 & 64.44 \\
\hline Black & 8 & 8.88 \\
\hline Brown & 22 & 24.44 \\
\hline Yellow & 2 & 2.22 \\
\hline Formal education & 97 & \\
\hline Illiterate & 2 & 2.06 \\
\hline IEE & 32 & 32.98 \\
\hline CEE & 20 & 20.61 \\
\hline IUSE & 4 & 4.12 \\
\hline CUSE & 28 & 28.86 \\
\hline IHE & 3 & 3.09 \\
\hline $\mathrm{CHE}$ & 8 & 8.24 \\
\hline Alcohol use & 99 & \\
\hline Yes & 86 & 86.86 \\
\hline No & 13 & 13.13 \\
\hline Smoking & 99 & \\
\hline Yes & 16 & 16.16 \\
\hline No & 81 & 81.81 \\
\hline Former smoker & 2 & 2.02 \\
\hline Illicit drug use & 99 & \\
\hline Yes & 2 & 2.02 \\
\hline No & 97 & 97.97 \\
\hline Physical activity & 99 & \\
\hline Yes & 30 & 30.30 \\
\hline No & 69 & 69.69 \\
\hline Variable & Median & Range \\
\hline Age & 60 & $19-81$ \\
\hline Income (R\$) & 2000 & $0-15000$ \\
\hline
\end{tabular}

Legend: $\mathrm{IEE}$ = Incomplete Elementary Education; $\mathrm{CEE}=$ Complete Elementary Education; IUSE = Incomplete Upper Secondary Education; CUSE = Complete Upper Secondary Education; $\mathrm{IHE}=$ Incomplete Higher Education; $\mathrm{CHE}=$ Complete Higher Education
Finally, the Anova and Kruskal-Wallis tests were applied to analyze the different demographic subgroups, based on the distribution of the data.

$P$ values lower than 0.05 and a confidence interval of $95 \%$ were considered significant.

\section{RESULTS}

We included a total of 99 patients. Demographic data are described in Table 1. Most patients were female (68.6\%), married (55.7\%), white (64.4\%) and with incomplete elementary education (32.9\%)

Regarding the patients' habits, most drank at least socially $(86.8 \%), 16.6 \%$ were smokers, and $2 \%$ former smokers; $69.6 \%$ were sedentary.

Upon completion of the Hads questionnaire for depression and anxiety, we observed that $24.24 \%$ of the patients had borderline or high levels of anxiety and 21.21 of depression.

The results on the relationships between the levels of anxiety, depression, and spirituality between themselves and between the demographic and socioeconomic data analyzed are presented in Table 2.

We observed a negative correlation between the levels of depression and spirituality $(\mathrm{rho}=-0.44, \mathrm{p}<0.001)$ (Figure 1A) and the levels of anxiety and spirituality $($ rho $=-0.232, p=0.02)$ (Figure 1B). No significant

TABLE 2. RELATIONSHIP BETWEEN THE LEVELS OF ANXIETY, DEPRESSION, AND SPIRITUALITY AND THE DEMOGRAPHIC AND SOCIOECONOMIC DATA.

\begin{tabular}{l|l|l|l|l|l|l} 
& \multicolumn{2}{l|l|}{ SRBP } & \multicolumn{2}{l|}{ HADS anxiety } & \multicolumn{2}{l}{$\begin{array}{l}\text { HADS Depres- } \\
\text { sion }\end{array}$} \\
\hline Variable & rho & $P$ & rho & $P$ & rho & $P$ \\
\hline Age & $-0,042$ & 0,676 & $-0,070$ & 0.49 & 0,047 & 0,641 \\
\hline Income & $-0,101$ & 0,365 & $-0,141$ & 0,206 & 0,123 & 0,912 \\
\hline Variable & $\begin{array}{l}\text { Medi- } \\
\text { an }\end{array}$ & $P$ & $\begin{array}{l}\text { Medi- } \\
\text { an }\end{array}$ & $P$ & $\begin{array}{l}\text { Medi- } \\
\text { an }\end{array}$ & $P$ \\
\hline
\end{tabular}

Formal education

\begin{tabular}{l|l|l|l|l|l|l}
\hline Higher & 128 & 0,442 & 6 & 0,498 & 2 & 0,426 \\
\hline Non-higher & 132 & & 4 & & 4.5 & \\
\hline
\end{tabular}

Marital status

\begin{tabular}{l|l|l|l|l|l|l}
\hline Married & 133 & 0,562 & 4 & 0,693 & 4 & 0,579 \\
\hline Single & 129 & & 5 & & 5 & \\
\hline
\end{tabular}

Ethnicity

\begin{tabular}{l|l|l|l|l|l|l|}
\hline White & 129 & 0,226 & 4.5 & 0,792 & 4 & 0,878 \\
\hline Non-white & 136 & & 5 & & 5 & \\
\hline Gender & \multicolumn{7}{|l|}{$\begin{array}{l}\text { Male } \\
\text { Female }\end{array}$} & 127 & 0,295 & 3 & 0,050 & 2 & 0,214 \\
\hline
\end{tabular}


difference was observed between the levels of anxiety, depression, or spirituality upon stratification by formal education, income, ethnicity, or marital status.

Finally, there was a positive correlation between the levels of anxiety and depression (cor $=0.477$, $\mathrm{p}<0.001)$.

\section{DISCUSSION}

Spirituality appears as an important ally for people who find themselves in adverse situations, particularly patients with psychiatric disorders and cancer patients 9 .

Increasingly, spirituality presents itself as an alternative and coping strategy in the face of situations considered difficult and impactful, as is the case of the diagnosis and treatment of cancer, which produces several stressful events. Some of the positive strategies associated with spirituality are: improvement of

FIGURE 1. CORRELATION BETWEEN THE LEVELS OF SPIRITUALITY ACCORDING TO THE WHOQOL-SRBP AND DEPRESSION (1A) AND ANXIETY (1B) BASED ON THE HADS

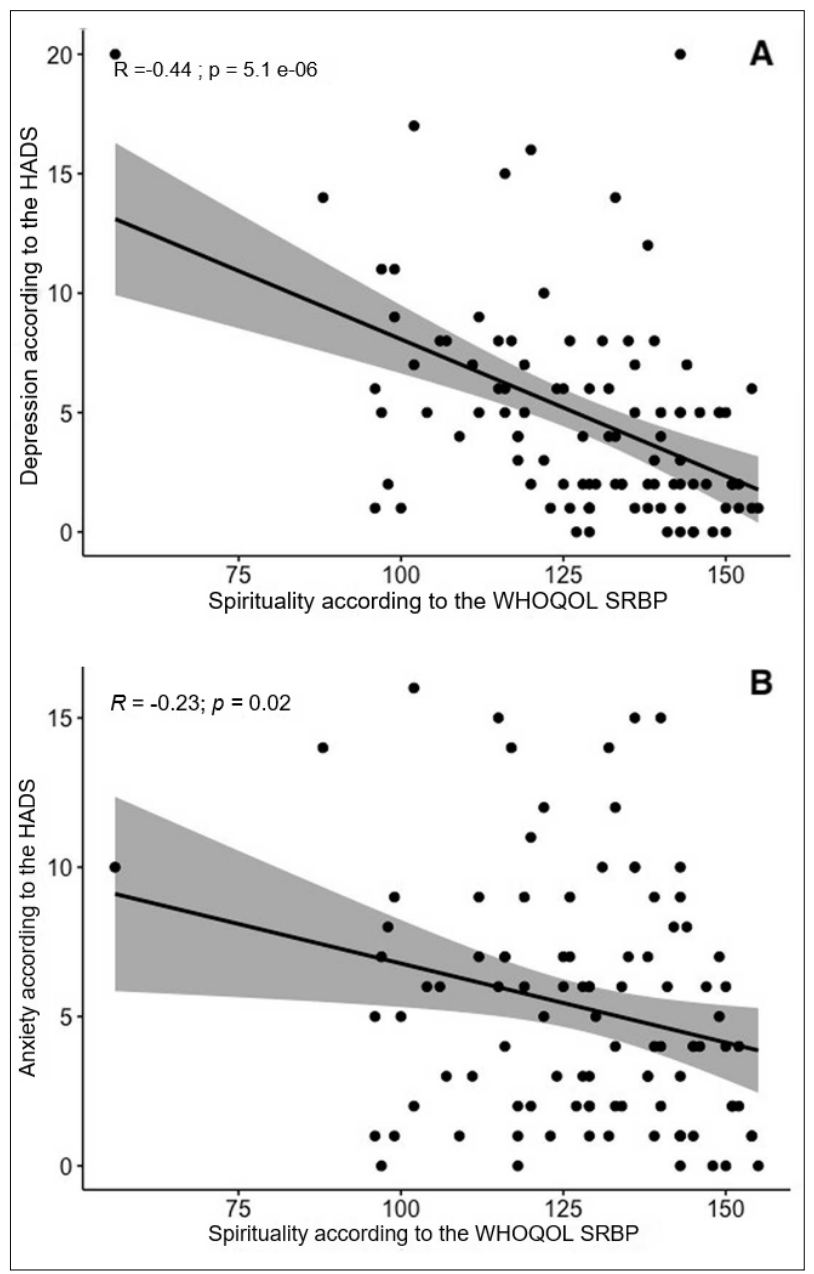

mental health, reduction of stress, spiritual growth, and colaboration ${ }^{15}$. The purpose of this study was to evaluate if correlations between the level of spirituality, demographic variables, and the presence of anxiety or depression are reproduced in our population.

According to the data studied, 21\% of the patients had borderline or high levels of depression, and there was a negative correlation between depression and spirituality. The findings of our study corroborate data from the literature, which found a negative correlation between depression and spirituality ${ }^{16.17}$. These findings suggest that the spiritual well-being, obtained from giving meaning to life or through religious practice, combined with physical well-being, is useful for handling depression.

The fact that spirituality is negatively correlated with depression and anxiety stressed the significant role of the spiritual state in the daily clinical practice of palliative care and for the preservation or improvement of emotional suffering, as well as in the control of symptoms ${ }^{18}$. It is worth noting that often there are factors that can influence patients' stage of depression, such as the time of diagnosis of neoplasia, age, among others, and these affect the positive understanding of spirituality.

We found that the higher the level of spirituality, the lower the level of anxiety. Although this finding is observed in other studies in the literature, the causal relationship and attempts at an explanation for this phenomenon vary and are still a topic for speculation $^{19}$. The findings suggest that the search for a meaning to life, peace and understanding of the universe through faith make the individual more aware of the process of becoming ill and the natural course of the disease itself, making the experience of the diagnosis, treatment, and follow-up more optimistic and positive. Prayer, through spirituality, also reliefs tension and increases hope, reducing the levels of anxiety ${ }^{20}$.

We observed a positive mean correlation between anxiety and depression evaluated by the Hads in our patients. Both depressive and anxiety disorders can lead to significant losses in the functioning of individuals, such as decreasing their self-esteem and increasing hopelessness in the case of depression, and feelings of fear and behavioral disturbance in anxiety. Although they are different disorders, symptoms may appear together ${ }^{21}$. Beck et al. ${ }^{22}$ reported that anxiety is a disorder often presented by depressive patients, particularly when they experience a worsening of depression. 
In our study, we observed women tend to have more anxiety $(p=0.05)$ in comparison with men.

Women have higher rates of prevalence of anxiety and mood disorders than men, who tend to have more problems related to the use of psychoactive substances and antisocial and schizotypal personality disorder. Female sex steroids, particularly estrogen, act in the modulation of mood, which explains the higher prevalence of mood and anxiety disorders in women ${ }^{23}$.

For Barlow ${ }^{24}$, women are more susceptible to stressful events in childhood and adolescence, which is associated with the perception that their behaviors cause little impact in the environment and may lead to a feeling of lack of control and the consequent development of pessimistic patterns of assessment of reality.

\section{Limitations}

This is a cross-sectional and observational study, therefore, relations of cause and effect cannot be established.

\section{CONCLUSION}

We found high levels of depression and anxiety among cancer patients. There was a negative correlation between the presence of depression and spirituality in these patients, which leads us to conclude that spirituality can be a complementary tool in the treatment of patients with cancer.

\section{RESUMO}

OBJETIVO: Relacionar os níveis de ansiedade e depressão com os de espiritualidade dos pacientes oncológicos da região do $A B C$.

MÉTODO: Estudo transversal realizado nos ambulatórios de oncologia do Centro Universitário ABC. Para avaliação da espiritualidade, foi aplicado o questionário Religiosidade, espiritualidade e crenças pessoais da Organização Mundial da Saúde (SRPB-WHO). Para avaliar os níveis de depressão e ansiedade foi aplicado a Hospital Anxiety and Depression Scale (Hads). Variáveis qualitativas foram descritas por frequência e porcentagem, as quantitativas por média e desvio padrão ou mediana e intervalo. Relações foram feitas por meio do teste de t ou Wilcoxon-Mann-Whitney e correlações pelo teste de Pearson ou Spearman, a depender da normalidade avaliada pelo teste de Shapiro-Wilk.

RESULTADO: Foram incluídos 99 pacientes; $68 \%$ do sexo feminino, mediana de idade 60 (19 a 81); 24\% tiveram níveis altos ou limítrofes para ansiedade e $21 \%$ para depressão. Foi observada correlação negativa entre os níveis de depressão e espiritualidade (rho=-0,44, $p<0,001$ ) e ansiedade e espiritualidade ( $r h o=-0,232, p=0,02$ ). Não foi observada diferença entre os níveis de ansiedade, depressão ou espiritualidade ao estratificar por escolaridade, renda, etnia ou estado civil. Houve correlação positiva entre os níveis de ansiedade e depressão (cor=0,477, $p<0,001)$

CONCLUSÃO: A espiritualidade pode ser uma ferramenta complementar a ser utilizada no tratamento do paciente com câncer.

PALAVRAS-CHAVE: Neoplasias. Espiritualidade. Depressão. Ansiedade.

\section{REFERENCES}

1. World Health Organization. Global health observatory data repository. Number of deaths (world) by cause. 2011. [cited 2019 Oct 7]. Available from: http://apps.who.int/gho/data/node.main.CODWORLD?lang=en.

2. Bray F. Transitions in human development and the global cancer burden In: Wild CP, Stewart B, eds. World cancer report 2014. Lyon: International Agency for Research on Cancer; 2014.

3. Barbosa IR, Souza DL, Bernal MM, Costa ICC. Cancer mortality in Brasil: temporal trends and predictions for the year 2030. Medicine (Baltimore). 2015;94(16):e746.

4. Peters E, Mendoza Schulz L, Reuss-Borst M. Quality of life after cancer: how the extent of impairment is influenced by patient characteristics. BMC Cancer. 2016;16(1):787.

5. World Health Organization (WHO). Depression and other common mental disorders: global health estimates. Geneva: World Health Organization; 2017.

6. Marcus M, Yasamy MT, van Ommeren M, Chisholm D, Saxena S. WHO Department of Mental Health and Substance Abuse. Depression: a global public health concern. Geneva: World Health Organization; 2012. [cited 2019 Oct 7]. Available from: https://www.who.int/mental_health/management/ depression/who_paper_depression_wfmh_2012.pdf
7. Üstün TB, Ayuso-Mateos JL, Chatterji S, Mathers C, Murray C). Global burden of depressive disorders in the year 2000. Br J Psychiatry. 2004;184:386-92.

8. Weissman MM, Bland RC, Canino G), Faravelli C, Greenwald S, Hwu HG Cross-national epidemiology of major depression and bipolar disorder. JAMA. 1996;276(4):293-9.

9. Balboni TA, Paulk ME, Balboni MJ, Phelps AC, Loggers ET, Wright AA, et al. Provision of spiritual care to patients with advanced cancer: associations with medical care and quality of life near death. I Clin Oncol. 2009;28(3):445-52.

10. Shin DW, Suh SY, Kim SH, Park J, Yoon SJ, Kim YJ, et al. Is spirituality related to survival in advanced cancer inpatients in Korea? Palliat Support Care. 2017;16(6):669-76.

11. Peterman $A H$, Reeve $C L$, Winford EC, Cotton S, Salsman IM, McQuellon $\mathrm{R}$, et al. Measuring meaning and peace with the FACIT-spiritual well-being scale: distinction without a difference? Psychol Assess. 2014;26(1):127-37.

12. Shahabi L, Powell LH, Musick MA, Pargament KI, Thoresen CE, Williams $\mathrm{D}$, et al. Correlates of self-perceptions of spirituality in American adults. Ann Behav Med. 2002;24(1):59-68. 
13. Zigmond AS, Snaith RP. The hospital anxiety and depression scale. Acta Psychiatr Scand. 1983;67(6):361-70.

14. Panzini RG, Maganha C, Rocha NS, Bandeira DR, Fleck MP. Brazilian validation of the Quality of Life Instrument/spirituality, religion and personal beliefs. Rev Saude Publica. 2011;45(1):153-65.

15. Fornazari SA, Ferreira RER. Religiosidade/espiritualidade em pacientes oncológicos: qualidade de vida e saúde. Psic: Teor e Pesq 2010;26(2):265-72.

16. Nelson C, lacobson CM, Weinberger MI, Bhaskaran V, Rosenfeld B, Breitbart $\mathrm{W}$, et al. The role of spirituality in the relationship between religiosity and depression in prostate cancer patients. Ann Behav Med. 2009;38(2):105-14.

17. Salsman JM, Yost KJ, West DW, Cella D. Spiritual well-being and health-related quality of life in colorectal cancer: a multi-site examination of the role of personal meaning. Support Care Cancer. 2001;19(6):757-64.

18. Bovero A, Leombruni P, Miniotti M, Torta R. Religiosity, pain and depression in advanced cancer patients. World Cult Psychiatry Res Rev. 2012;8(1):51-9.
19. Kandasamy A, Chaturvedi SK, Desai G. Spirituality, distress, depression anxiety, and quality of life in patients with advanced cancer. Indian | Cancer. 2011;48(1):55-9.

20. Johnson KS, Tulsky JA, Hays IC, Arnold RM, Olsen MK, Lindquist JH, et al. Which domains of spirituality are associated with anxiety and depression in patients with advanced illness? J Gen Intern Med. 2011;26(7):751-8.

21. Baptista MN, Carneiro AM. Validade da escala de depressão: relação com ansiedade e stress laboral. Estud Psicol. 2011;28(3):345-52.

22. Beck TA, Rush AJ, Shaw BF, Emery G. Terapia cognitiva da depressão. Rio de Janeiro: Zahar; 1982.

23. Andrade LHSG, Viana MC, Silveira CM. Epidemiologia dos transtornos psiquiátricos na mulher. Rev Psiquiatr Clín. 2006;33(2):43-54.

24. Barlow DH. Anxiety and its disorders: the nature and treatment of anxiety and panic. 2nded. New York: Guilford Press; 2002. 